\title{
O PROCESSO PENAL ELEITORAL E A GARANTIA DE AMPLA DEFESA E CONTRADITÓRIO, EM FACE ÀS ALTERAÇÕES IMPOSTAS PELA LEI No 11.719/2008
}

\author{
The Electoral Criminal Process in Brazil and Audi Alteram Partem after \\ Law 11719/2008
}

\section{Marco Aurélio Rodrigues da Cunha e Cruz Adriana Martins Ferreira Festugatto Guilherme Apolinário Aragão}

Resumo: A Lei no 11.719/08 alterou substancialmente o Código de Processo Penal para privilegiar a celeridade, a defesa efetiva, o sistema acusatório e o contraditório, adequando suas disposições à Constituição de 1988. O presente texto tem por objetivo examinar os reflexos dessa alteração normativa no processamento dos crimes eleitorais, que, apesar de deter regras próprias previstas no Código Eleitoral, ampara-se subsidiária e expressamente nas disposições do Código de Processo Penal. O artigo defende a tese jurídica da aplicação dos critérios da hierarquia e da temporalidade, para a solução dessa antinomia jurídica, com fundamento jurisprudencial no REspe no 2-75.2014.6.13.0044, de 2018. O referencial teórico adotado é o sistema jurídico de Kelsen. Utilizou-se de pesquisa bibliográfica e documental e uma abordagem dedutiva para estabelecer uma relação lógica e ordenada entre as proposições apresentadas. Como principais resultados, evidenciou-se que o entendimento correto é que houve a derrogação tácita dos artigos 359 e 360, do Código Eleitoral, devendo ser adotado o rito processual mais benéfico ao acusado, nos termos da Constituição de 1988 e da Lei $\mathrm{n}^{\circ}$ 11.719/08.

Palavras-chave: Direitos humanos. Devido processo legal. Processo penal eleitoral. Antinomia. Ampla defesa.
Abstract: Law 11719/08 changed the Penal Procedure Code to improve speed, effective defense, the accusatory, and the adversarial system, adapting the code to the Brazilian Constitution of 1988. This article examines the consequences of this normative change in processes regarding electoral crimes, which is subsidiary and expressly supported by the provisions of the Code of Criminal Procedure, despite having its own rules provided by the Electoral Code. The study defends the legal thesis of applying hierarchy and temporality criteria to solve this legal antinomy based on jurisprudence in RESPE 2-75.2014.6.13.0044 (2018). The theoretical framework adopted is the Kelsen legal system. Bibliographic and documentary research was used with an approach to establish a logical and orderly relationship between the provisions presented. In summary, it was evidenced that the correct understanding is the tacit derogation of art. 359 and 360 of the Electoral Code. The most beneficial procedural rite to the accused must be adopted, as determined by the terms of the 1988 Constitution and Law 11719/08.

Keywords: Human rights. Due legal process. Electoral criminal proceedings. Antinomy. Audi Alteram Partem.

Artigo recebido em 7 set. 2020 e aprovado em 8 out. 2020 . 


\section{Introdução}

O devido processo legal, enquanto um direito fundamental (art. 5, LIV, CF/88) e como um dos direitos humanos (art. 11, DUDH/1948; art. 14, Decreto 592/92; art. 8으, Decreto 678/92), pauta-se, sobretudo, na presunção de inocência (art. 5, LVII, CF/88) a todo aquele acusado de ato delituoso, guardando ligação indissociável com a garantia do contraditório e da ampla defesa (art. 5ㅜ, LV, CF/88). A Lei no 11.719/08 alterou substancialmente o Código de Processo Penal (CPP), de 1941, para privilegiar à defesa efetiva, sem perder de vista a celeridade e o próprio sistema acusatório, adequando as disposições desse ao valores expressos na Constituição de 1988 (CF/88), dentro do regime de direitos e garantias fundamentais inerentes ao Estado Democrático de Direito. Entre outros pontos, a referida legislação modificou substancialmente a audiência de instrução e julgamento penal, ao determinar que o interrogatório do réu seja o último ato instrutório, antes da sentença.

Por outro lado, o Código Eleitoral (CE), de 1965, traz previsão em seu artigo 359, de rito processual penal pelo qual o depoimento do acusado é o primeiro ato da fase instrutória, e portanto, não guarda similitude com a nova sistemática do Código de Processo Penal. O objetivo deste artigo científico, portanto, é investigar os reflexos jurídicos da alteração normativa no CPP no que se refere ao processamento dos crimes eleitorais, o qual - apesar de deter regras próprias previstas no Código Eleitoral - ampara-se subsidiária e expressamente às disposições previstas naquele. $\mathrm{O}$ artigo defende a tese jurídica da aplicação dos critérios da hierarquia (lex superior derogat inferior) e da temporalidade (lex posterior derogat priori) para a solução dessa antinomia jurídica.

Para demonstrar a consistência desse argumento, a partir de pesquisa bibliográfica e documental, num primeiro momento será apresentado o contexto social que circunda os dois diplomas legais em conflito, a fim de evidenciar a antinomia das normas numa linha temporal e hierárquica. Após, analisa-se a solução da problemática pelo prisma jurisprudencial (Agravo Regimental em Recurso Especial Eleitoral nº 2-75.2014.6.13.0044) e doutrinário, com referencial teórico de sistema jurídico de Hans Kelsen (2000). A abordagem é dedutiva, para estabelecer uma relação lógica e ordenada entre as proposições apresentadas. Ao final, serão ofertadas notas conclusivas. 


\section{As Constituições de 1937 e de 1988, o Código de Processo Penal e a Lei no ${ }^{\mathbf{1 1}}$.719/08}

Antes de 3 de outubro de 1941, cada Estado membro possuía seu Código de Processo Penal (CPP). Contudo, a unificação de códigos passou a ser uma questão política primordial, aparecendo elencada como um dos motivos centrais para a edição do CPP em 1941. Dentro desse projeto dar unidade, o Presidente da República, com fundamento no artigo 180 da Constituição Federal de $1937^{1}$, valendo-se da ausência do Congresso Nacional dissolvido desde 1937, expediu o Decreto-Lei no 3.689/41, que deu origem ao Código de Processo Penal nacional.

Vale registrar, contudo, que na Constituição de 1937 predominava o caráter de autoritarismo, não havendo qualquer eleição durante toda a sua vigência (VILLA, 2011, p. 68). Da leitura de seu texto, extrai-se que o chefe do Executivo foi posto no centro de todo o cenário político-constitucional, concentrando em sua figura "os órgãos representativos de grau superior, dirigia a política interna e externa, promovia política legislativa e geria a administração do país [...] se espraiava pelos Estados, sujeitos à nomeação de interventores.” (GOMES e ZAMARIAN, 2012, p. 75).

Francisco Campos, que já havia sido responsável pela redação da Constituição de 1937, também foi escolhido para a redigir o CPP. Era esperado, portanto, que o CPP refletisse os valores da Constituição de 1937. $\mathrm{E}$, de fato, as proporções foram ligeiramente além do balizamento, pois presentes os ideais defendidos pelo autor, que podem ser traduzidos em algumas de suas celebres frases: "governar é prender"; "O povo não precisa de governo, precisa de curatela". Assim, Francisco Campos ficou conhecido como expoente do pensamento autoritário (SANTOS, 2007).

Com um autor não-democrata, somado a uma Constituição eminentemente autoritária, o resultado somente poderia ser um CPP que presumia a culpabilidade do réu, que é o que se infere da exposição de motivos do CPP/1941. Sem maiores digressões, a simples leitura do preâmbulo coteja a diferença essencial entre a Carta Constitucional/1937, que regime de origem do CPP, e a Constituição atualmente vigente. Nessa, o constituinte expõe sobre os valores sociais e individuais, a liberdade, a segurança,

\footnotetext{
${ }^{1}$ BRASIL. Constituição (1937). Constituição dos Estados Unidos do Brasil, de 1937: “Art. 180 - Enquanto não se reunir o Parlamento nacional, o Presidente da República terá o poder de expedir decretos-leis sobre todas as matérias da competência legislativa da União”.
} 
o bem-estar, o desenvolvimento, a igualdade, a justiça como valores supremos, sobre os quais o Plenário do Supremo Tribunal Federal (STF) afirma princípio jurídico da solidariedade [ADI 2.649, voto da rel. min. Cármen Lúcia, j. 8/5/2008, DJe de 17-10-2008.] Esses valores foram completamente inexistentes na Carta de 1937.

O texto constitucional de 1988, pois, adotou o Estado Democrático de Direito e rompeu com uma sucessão de governos autoritários em que o Estado prevalecia em detrimento do indivíduo (GOMES e ZAMARIAN, 2012, p. 140). Em razão dessas mudanças da ordem que rege a edição de leis e dita a compatibilidade das normas pretéritas, foi questão de tempo para que o recepcionado CPP se curvasse aos novos ditames constitucionais, como escreveram Maria Thereza Rocha de Assis Moura e Leandro Galluzzi dos Santos (2009, p. 181):

O Brasil do Estado Novo não é o Brasil da virada do milênio. O reconhecimento de novas garantias, o avanço dos direitos fundamentais e a redemocratização do país fizeram com que a sistemática processual fosse intensamente modificada e por tal razão a tão esperada reforma estrutural do Código de Processo Penal é indispensável para que este seja inteiramente condizente com a base fundamental da Carta Magna, qual seja, a dignidade de pessoa humana.

Reputa-se, contudo, que as alterações trazidas até o momento ainda não foram suficientes para alinhar, completamente, o CPP à Constituição de 1988. Sem dúvida, a Lei no 11.791/08 revelou um passo importante nesse sentido ao alterar o rito do processo penal, tornando-o mais favorável ao réu.

No formato original do CPP, o artigo 394 previa que ao receber a peça acusatória, incumbia o juiz designar o interrogatório, ordenando a citação do réu. Em sequência, o artigo 395 do CPP previa que o prazo para apresentação da defesa e para arrolar testemunhas, passaria a fluir somente após o interrogatório. O rito seguia com a oitiva das testemunhas, principiando pelas arroladas pelo parquet e então as de defesa. Ouvidas as testemunhas, os autos seguiam para razões finais e encerrava-se a instrução processual. Com o interrogatório como ato inaugural do réu no processo, as testemunhas e o Ministério Público podiam se valer de tudo que foi dito pelo réu para concatenarem a verdade processual que lhes aprouvesse, afora que o réu teria que passar por todas as agruras do processo penal para somente ao final ser absolvido, ainda que sua inocência fosse presumida. 
De autoria do Poder Executivo, o Projeto de Lei no 4.207/01 visou privilegiar a celeridade, a defesa efetiva, o sistema acusatório e o contraditório, e possuía como principais inovações: a defesa do acusado antes do exame de admissibilidade da denúncia; a fundamentação da decisão que a recebe ou rejeita a denúncia; o interrogatório do acusado após toda a produção da prova; a faculdade da rejeição liminar da peça acusatória ou de absolvição sumária, facultada a produção de provas.

Assim, confrontando as alterações até então pretendidas com os preceitos constitucionais, pode-se confluir que a reforma implementada pela Lei n⿳⺈ 11.719/08 visou atender os seguintes comandos constitucionais: artigo $5^{\circ}$, inciso LVII que trata sobre a presunção de inocência; artigo 93, inciso IX que aduz sobre a fundamentação das decisões judiciais; artigo $5^{\circ}$, inciso LXIII, que veda a autoincriminação; artigo 5, inciso LV, que assegura a ampla defesa e o contraditório.

A Lei n 11.719/08 inova no CPP a partir do momento anterior à recepção da denúncia, ao prescrever no artigo 395 do CPP, que o juiz pode rejeitar liminarmente a denúncia por inépcia, defeito formal; ausência de pressuposto processual ou condição da ação; ou justa causa. Aceita a denúncia, será determinada a citação do réu para apresentar sua defesa no prazo de 10 (dez dias) (art. 396, do CPP). Em seguida, faz-se presente o instituto da absolvição sumária, insculpido no artigo 397 do CPP, em que poderá ser absolvido o réu caso se verifique: a existência manifesta de causa excludente da ilicitude do fato; a existência manifesta de causa excludente da culpabilidade do agente, salvo inimputabilidade; que o fato narrado evidentemente não constitui crime; extinta a punibilidade do agente.

Até o presente estágio processual, o acusado/réu pode esquivar-se por duas vezes da incidência penal: a primeira pela rejeição da denúncia e a segunda pela absolvição sumária, ou seja, não precisaria enfrentar todo o procedimento da instrução processual para ao final ser inocentado, o que inclusive é um fator que contribui para eliminar a quantidade de processos desnecessários que abarrotam o Judiciário. A próxima etapa passou a ser a designação da audiência de instrução que deverá ser única, como prevê o artigo 411 do CPP, sendo que é a oportunidade de produção de prova técnica e testemunhal, e o interrogatório do réu tornou-se o último ato dessa instrução. Em seguida, são ofertadas as alegações finais orais, acompanhadas pela sentença que põe fim a provimento jurisdicional de primeira instância. 
O interrogante a ser levantado é sobre a adequação dessas novas premissas legais ao direito eleitoral. A resposta será deduzida a seguir.

\section{O Processo Penal Eleitoral e a antinomia com a nova redação do Código de Processo Penal}

O Código Eleitoral, instituído pela Lei no 4.737, de 15 de julho de 1965, sob o governo militar de Castello Branco e égide da Constituição de 1946, permanece vigente até os dias atuais, com alterações pontuais. Inicialmente, segundo o que apontam as fontes históricas, a constituinte de 1946 partiu do zero, não buscando inspiração em qualquer outro texto constitucional vigente ou pretérito, nacional ou de outro país (BALEEIRO e LIMA SOBRINHO, 2012, p. 9).

Um paradigma externo importante que marcou a necessidade de edição de uma nova Constituição à época, foi a segunda grande guerra mundial, principiada em 1939 e finda em 1945, pois criou um paradoxo. Em 1942, o Brasil aliou-se ao lado democrático do conflito, liderado por Estados Unidos, Grã-Bretanha e França, o que contrastava fortemente com os flertes que o Governo Vargas tinha com o fascismo. Pelo plano traçado, finalmente seria convocado o plebiscito para validação da Constituição de 1937, o que todavia não pode ser concretizado. Foi editado, então, o Decreto-Lei no 7.586 que recriou o Tribunal Superior Eleitoral e fixou-se o dia em 2 de dezembro de 1945 para a eleição geral ${ }^{2}$.

Dentro do contexto acima traçado, surgiu a dúvida se os parlamentares eleitos seriam responsáveis também pela edição da nova constituição, o que foi respondido por meio da Resolução nº 215, de 2 de dezembro de 1945, que afirmou a competência ordinária, constitucional e ilimitada dos eleitos.

Assim, em 18 de setembro de 1946 promulgou-se a Constituição dos Estados Unidos do Brasil, que foi a base para o que temos hoje como organização estatal, sendo fortemente democrática (BONAVIDES e ANDRADE, 2004, p. 415). Pela ótica proposta por J.J Canotilho (2000, p. 52), os requisitos essenciais de um texto constitucional foram cumpridos, a saber: a tripartição de poderes, o sufrágio, os direitos fundamentais.

\footnotetext{
${ }^{2}$ Para ler mais: BRASIL. TRIBUNAL SUPERIOR ELEITORAL. Assembleia Constituinte de 1946. Disponível em: <http://www.tse.jus.br/jurisprudencia/julgados-historicos/assembleia-constituinte-1946>. Acesso em: 6 jul. 2020.
} 
De 1946, com a promulgação da nova constituição, até edição do Código Eleitoral, em 1965, vários acontecimentos permearam a sociedade brasileira, dentre eles o de maior destaque foi o ato militar do dia 31 de março de 1964 contra o governo de João Goulart. A ditatura militar perdurou no poder até o ano de 1985, cujas principais marcas foram a edição de atos institucionais (CASTRO, s/a) e supressão de direitos e garantias fundamentais. O processo eleitoral não escapou ileso e foi alterado por atos institucionais, emendas constitucionais, leis e decretos-leis ${ }^{3}$ que culminaram na alteração da duração de mandatos, cassação de direitos políticos, eleições indiretas para presidente da República, governadores dos estados, dos territórios, para prefeitos dos municípios considerados de interesse da segurança nacional e das estâncias hidrominerais, candidaturas natas, voto vinculado, sublegendas, alteração do cálculo para o número de deputados na Câmara, com base ora na população, em detrimento dos estados tradicionalmente mais expressivos. Tudo isso que reforçou a discricionariedade do chefe do Executivo.

No dia 15 de abril de 1964, Castelo Branco assumiu a presidência e em seguida determinou ao Tribunal Superior Eleitoral a elaboração de um novo Código Eleitoral para posterior submissão ao legislativo. Instituiu-se uma comissão de trabalho presidida pelo ministro Antônio Vilas Boas e tendo como componentes Décio Miranda, Colombo de Sousa e Geraldo da Costa Manso (FICHTNER e GAMA FILHO, s/a).

O projeto do TSE foi enviado à Câmara do Deputados, onde tramitou sob o n⿳2 2745, com a relatoria do deputado Ulisses Guimarães, que anos depois seria um dos principais protagonistas da Constituição de 1988. Após receber 127 emendas, o texto foi submetido a sanção presidencial e em 15 de julho de 1965 foi promulgado o Código Eleitoral, Lei nº 4.737.

Entretanto, conjugando-se o período vivido pelo país após o ato militar de 1964, pode-se instar que o Código Eleitoral de 1965 é um verdadeiro paradoxo, pois visava tutelar o exercício do sufrágio dentro de um regime eminentemente ditatorial, que desrespeitava os preceitos da constituição vigente à época. Diante desse cenário, as prescrições que tratam acerca do Processo Penal Eleitoral, previstas no Código Eleitoral de 1965, são norteadas por princípios eminentemente autoritários.

\footnotetext{
${ }^{3}$ Para ler mais sobre a história da Justiça Eleitoral, ver: <http://www.tse.jus.br/o-tse/ cultura-e-historia/historia-do-tse $>$ e <http://www.tre-pi.jus.br/institucional/o-tre-pi/ memoria-e-cultura/evolucao-da-justica-eleitoral-no-brasil>. Acesso em: 6 jul. 2020.
} 
A presença de um sistema sancionatório no âmbito do Direito Eleitoral dá-se com o fito de que seus valores, estruturas e funções se mantenham hígidas, evitando o colapso do próprio sistema eleitoral, o qual contempla vários tipos de sanções: inelegibilidade; negativa de registro de candidatura; perda de registro de candidatura; negativa de expedição de diploma; cassação de diploma; cassação de mandato; multa; restauração de bem; retirada de propaganda; perda do direito à veiculação de propaganda; perda de tempo no horário eleitoral gratuito; suspensão da programação normal de emissora de rádio ou televisão (GOMES, 2016, p. 734). Dentro deste contexto, o Direito Penal revela-se como ultima ratio, para a proteção da sociedade e do indivíduo.

Sem embargo, retornando ao Processo Penal Eleitoral, e em que pese a distância temporal, a parte que trata do processo penal no âmbito eleitoral foi integralmente inspirada no CPP de 1941. Já após a Constituição de 1988, a Lei no 10.732, de 5 de setembro de 2003 alterou a redação do art. 359 da Lei n⿳⺈ 4.737, de 15 de julho de 1965 - Código Eleitoral (CE), para instituir a obrigatoriedade do depoimento pessoal no Processo Penal Eleitoral. Conforme redação do artigo 359, com o recebimento da denúncia pelo Juiz Eleitoral, o interrogatório é designado, sendo o primeiro ato do qual o réu participa no PPE. O parágrafo único do mesmo artigo, confere ao réu 10 (dez) dias para apresentação de sua defesa escrita e para arrolar testemunhas. Após a realização do interrogatório, ouvidas as testemunhas, realizadas as diligências, o MP e a defesa terão o prazo de 10 (dias) para apresentar as alegações finais escritas, assim reza o artigo 360. Em seguida, o artigo 361 confere o prazo de 48 (quarenta e oito) horas para que os autos sigam conclusos ao Juiz Eleitoral, cabendo proferir sentença no prazo de 10 (dez) dias.

Com o advento da Lei $\mathrm{n}^{\circ}$ 11.719/08, nasceu uma discrepância normativa entre o CPP e o CE. O rito da audiência previsto no artigo 359 do CE, com o depoimento do acusado como o primeiro ato processual (2003), não é coerente com a nova sistemática (2008), pois passou a ser o último ato antes da prolação da sentença.

Não obstante, cumpre explicitar que o artigo 397 do CPP passou a trazer a possibilidade de absolvição sumária, e constitui significativa evolução no processo penal, pois permite ao réu não ter que passar por todo o rito processual para ser absolvido, de uma acusação que é manifestamente fadada ao fracasso, o que não encontra correspondência no CE. Assim, 
cotejando-se o rito da audiência na redação originária do CPP com a nova redação, pode-se estabelecer o seguinte quadro:

\begin{tabular}{|c|c|c|}
\hline Ato $n^{o}$ & $\begin{array}{c}\text { CPP na redação antiga e do } \\
\text { CE }\end{array}$ & $\begin{array}{c}\text { CPP na redação da Lei } n^{\circ} \\
11.719 / 08\end{array}$ \\
\hline 1 & Denúncia & Denúncia \\
\hline 2 & Recebimento & Recebimento \\
\hline 3 & Citação & Citação \\
\hline 4 & Interrogatório do Acusado & Defesa Escrita \\
\hline 5 & Defesa Prévia & Absolvição Sumária \\
\hline 6 & $\begin{array}{c}\text { Audiência de Instrução e } \\
\text { Julgamento }\end{array}$ & $\begin{array}{c}\text { Audiência de Instrução e } \\
\text { Julgamento }\end{array}$ \\
\hline 7 & Testemunhas Acusação & Oitiva da vítima \\
\hline 8 & Testemunhas Defesa & Testemunhas Acusação \\
\hline 9 & Diligências & Testemunhas Defesa \\
\hline 10 & Alegações Finais & Peritos \\
\hline 11 & Sentença & Acareação \\
\hline 12 & & Reconhecimento \\
\hline 13 & & Interrogatório do Acusado \\
\hline 14 & & Alegações Finais \\
\hline 15 & & Sentença \\
\hline
\end{tabular}

Delineadas as mudanças implementadas pela Lei $\mathrm{n}^{\underline{0}}$ 11.719/08, que podem influenciar no rito do Processo Penal Eleitoral, convém identificar quais os princípios constitucionais que segundo o projeto de lei foram baluartes para a novidade legislativa, frisa-se: celeridade, à defesa efetiva, o sistema acusatório e o contraditório.

Com efeito, é procedente a tese jurídica de que esses preceitos constitucionais que ocasionaram a mudança do CPP no ano de 2008 também devem nortear o Processo Penal Eleitoral, em especial atentando-se que o Código Eleitoral em seu artigo 364 aduz que "no processo e julgamento dos crimes eleitorais e dos comuns que lhes forem conexos, assim como nos recursos e na execução, que lhes digam respeito, aplicar-se-á, como lei subsidiária ou supletiva, o Código de Processo Penal”.

A referida redação deixa claro que o CPP e o CE não são dissociados, mas guardam uma imanente relação jurídico-legislativa, em decorrência da importância do direito material a que dão suporte, pois como 
se sabe o Direito Penal é ultima ratio. Todavia, cumpre investigar se o CE continuaria sendo aplicado no tocante a instrução processual penal, preservando-se o disposto no artigo 364 do CE, que reserva ao CPP a mera subsidiariedade ou supletividade ou se houve a revogação tácita das disposições processuais penais no CE, em razão das alterações implementadas pela Lei no 11.719/08, que foi editada para adequar o CPP aos preceitos da Constituição de 1988.

\section{A solução da antinomia pelo prisma jurisprudencial e doutrinário}

Para reforçar a defesa da aplicação das regras jurídicas da Lei $n^{\circ}$ 11.719/08 no Direito Eleitoral, oportuno faz-se analisar o precedente encontrado no Tribunal Superior Eleitoral a respeito da antinomia tida entre a nova redação do Código de Processo Penal e o Código Eleitoral, o que permitirá trazer um indicador do que a jurisprudência especializada tem de adotar.

Trata-se do REspe - Agravo Regimental em Recurso Especial Eleitoral n⿳⺈ 2-75.2014.6.13.0044, de Relatoria do Ministro Tarcísio Vieira de Carvalho Neto, julgado em 08 de março de 2018. Nesse caso, o Ministério Público Eleitoral insurgiu-se contra decisão que havia negado seguimento ao recurso especial interposto em face de acórdão do Tribunal Regional Eleitoral de Minas Gerais (TRE/MG). Essa Corte, por maioria, havia acolhido preliminar de cerceamento de defesa para anular o processo e determinar a remessa do feito à zona eleitoral de origem, a fim de que fosse realizado novo interrogatório dos denunciados, como último ato da instrução criminal, em observância ao art. 400 do CPP. Foi aduzido pelo recorrente que o procedimento aplicável na espécie seria o previsto no art. 359 do CE, e não o do art. 400 do CPP, com redação dada pela Lei no ${ }^{11.719 / 2008 . ~}$ Por outro lado, afirmou-se que a jurisprudência do TSE sedimentou-se no sentido de ser necessária a demonstração de efetivo prejuízo à defesa para que se declare nulidade, o que não foi observado pelo acórdão recorrido, que apenas presumiu o dano ao direito de defesa dos réus.

Em decisão monocrática, o relator negou prosseguimento ao recurso especial, embasando-se em entendimento jurisprudencial do STF, no julgamento do $\mathrm{HC}_{\mathrm{n}} \mathrm{N}$ 127.900, de relatoria do Ministro Dias Toffoli, de que o art. 400 do CPP deve ser aplicado em processos penais de legislação exor- 
bitante, incluindo a seara eleitoral. Consignou, ainda, que o exame quanto à configuração do cerceamento de defesa em razão da não observância do art. 400 do CPP demandaria a reincursão sobre fatos e provas, sendo a via extraordinária inadequada para tal fim, nos termos da Súmula no 24, do TSE.

Mencionou ainda as razões expostas no voto proferido pelo relator no acórdão regional, o qual enfatizou que a simples aplicação dos critérios de especificidade conflitaria com os valores constitucionais que devem nortear o processo penal durante toda a prestação jurisdicional pelo Estado. Assim, para a escolha da regra aplicável, deve-se invocar critério hermenêutico, que se legitima em razão de se mostrar mais compatível com os postulados que informam o estatuto constitucional do direito de defesa. No mesmo sentido, fez menção ao HC nº 69-09/MT, de relatoria do Min. Dias Toffoli:

HABEAS CORPUS. DENÚNCIA RECEBIDA PELO MAGISTRADO DE PRIMEIRO GRAU QUANDO O ACUSADO ESTAVA AFASTADÓ DO CARGO DE PREFEITO, EM VIRTUDE DA CASSAÇÃO DO MANDATO EM SEDE DE AIME. REASSUNÇÃO POSTERIOR AO CARGO. CONVALIDAÇÃO DOS ATOS. INTERROGATÓRIO DO RÉU NA AUDIÊNCIA DE INSTRUÇÃO E JULGAMENTO. ATO FINAL DA FASE INSTRUTÓRIA. ADOÇÃO DO RITO MAIS BENÉFICO DOS ARTS. 396 E SEGUINTES DO CPP AO PROCESSO PENAL ELEITORAL. ORDEM PARCIALMENTE CONCEDIDA. Não padece de nulidade a decisão do magistrado eleitoral que recebe denúncia contra o acusado que, à época, estava afastado do cargo de prefeito, em razão da procedência de ação de impugnação de mandato eletivo. A posterior diplomação em cargo com prerrogativa de foro, que importe em modificação superveniente de competência, não invalida os atos já praticados no processo, nem exige a respectiva ratificação. Precedente. Ainda que o acórdão regional que anulou a sentença de procedência da AIME tenha sido proferido antes do recebimento da denúncia pelo juiz de primeiro grau, a Corte Regional não determinou a execução imediata do julgado, o que afasta a competência por prerrogativa de -foro, que AgR-REspe no 2-75.2014.6.1 3.0044/MG 12 somente veio a incidir após a concessão de liminar que determinou a recondução do ora paciente ao cargo de prefeito. Sendo mais benéfico para o réu o rito, do art. 400 do Código de Processo Penal, com a redação dada pela Lei n. 11.719/2008, que 
fixou o interrogatório do como ato derradeiro da instrução penal, o procedimento deve prevalecer nas ações penais eleitorais originarias, em detrimento do previsto no art. 70da Lei oํ 8.038/90. Precedentes do STF e desta Corte. Ordem parcialmente concedida para determinar que seja obedecida a disciplina do art. 400 do CPP, em harmonia com o rito dos arts. 396 e seguintes. (HC n. 69-09/MT, ReI. Min. Dias Toffoli, RJTSE de 29.10.2013, DJe de 12.2.2014)

Com efeito, nesse julgamento houve menção às premissas constitucionais envolvidas, como a ampla defesa e o contraditório, tendo os ministros ultrapassado a questão da lei especial que revoga lei geral, com base em aplicação sistemática do direito, decidindo pela aplicação do CPP quando presente antinomia com lei especial.

A partir do precedente analisado, pode-se concluir que o TSE se posicionou a favor da aplicação da nova redação do CPP (2008) ao Processo Penal Eleitoral, em detrimento da regra contida no CE (2003). Resta configurada a derrogação tácita da regra contida nos artigos 359 e 360, desse último. Observa-se que o TSE, ao optar pela interpretação sistemática do ordenamento jurídico, exaltou a força normativa da Constituição sobre as leis infraconstitucionais. Em decorrência do Tribunal Superior Eleitoral ocupar o topo da pirâmide desta justiça especializada, representa uma tendência para os demais Tribunais Regionais e Juízos Eleitorais espalhados pelo território nacional, em se curvar ao entendimento.

O posicionamento tomado por parte dessa Corte demonstra a aplicabilidade aos direitos fundamentais e princípios constitucionais, assegurando o pleno gozo dos direitos previstos na Constituição de 1988, ainda que exista norma no ordenamento em sentido contrário. Tal postura corrobora a ideia de que a leis editadas sob o pálio das constituições pretéritas, por vezes, outorgadas em períodos sombrios da história nacional, constituídos pela mais nítida ausência do sufrágio e da tripartição de poderes, com relativização dos direitos fundamentais, podem chocar com os preceitos da Constituição de 1988. Nessa senda, a decisão do TSE traduz a prevalência da Constituição sob a legislação ordinária.

Registre-se, porém, que nem sempre foi esse o entendimento perante o TSE, visto que até então havia uma tendência em aplicar o CE/65 para os procedimentos penais eleitorais em detrimento das novas disposições do CPP, conforme se pode observar em inúmeros julgados ( $\mathrm{HC}$ nํㅡㄹ 2957- 
19.2010.6.00.0000 e AR no REspe no 23-52.2012.6.26.0305, por exemplo). Contudo, com a inovação legislativa imposta pela Lei no $11.719 / 08$, restou evidente que estamos diante de uma situação de antinomia jurídica, conceituada por Bobbio (1995, p. 86) como “aquela situação na qual são colocadas em existência duas normas, das quais uma obriga e a outra pró́be, ou uma obriga e a outra permite o mesmo comportamento". É neste sentido que é coerente e consistente a tese jurídica da aplicação dos critérios da hierarquia (lex superior derogat inferior) e da temporalidade (lex posterior derogat priori) para a solução desta antinomia jurídica.

Já Hans Kelsen (2000) defendia que o Direito é autopoiético, ou seja, apenas o Direito pode permitir a inserção de novas normas dentro do sistema jurídico. Neste trabalho, para elucidação do tema proposto serão analisadas duas de suas obras, Teoria Pura do Direito (1999) e Teoria Geral do Direito e do Estado (2000).

$\mathrm{Na}$ primeira obra supramencionada, Kelsen afirma que toda norma busca sua validade em uma norma superior e ao se chegar na norma que daria fundamento às demais, haveria uma norma pressuposta que seria a norma fundamental. A partir desse contexto, em que a norma fundamental daria validade a todas as demais, surgiria a noção de sistema. O ordenamento jurídico consistiria desta forma num sistema dinâmico, uma unidade composta por uma pluralidade que não se contradiz. Todavia, embora coexistindo num mesmo sistema, algumas normas podem contrapor-se, emergindo o que se chama de conflito normativo.

Além do critério lex posterior derogat priori, Kelsen (1999, p. 146) estabelece o seguinte para a solução de conflitos normativos:

Entre uma norma de escalão superior e uma norma de escalão inferior, quer dizer, entre uma norma que determina a criação de uma outra e essa outra, não pode existir qualquer conflito, pois a norma do escalão inferior tem o seu fundamento de validade na norma do escalão superior. Se uma norma do escalão inferior é considerada como válida, tem de se considerar como estando em harmonia com uma norma do escalão superior.

Assim, por acreditar que as normas inferiores respeitam as superiores, pode-se sintetizar o pensamento de Kelsen com o brocardo: lex superior derogat inferior. Com esses critérios, Kelsen encerra suas colocações nesta obra a respeito do tema aqui proposto. 
No livro Teoria Geral do Direito e do Estado (2000), Kelsen segue defendendo a existência de uma norma superior, com a consequente hierarquização das normas que gera a noção de sistema jurídico e forma uma unidade. A obra traz que a Constituição pode determinar o conteúdo de leis futuras, tanto positiva, quanto negativamente. Daí nasceriam as normas gerais, de cunho formal (processual) ou material, que dependem uma da outra para serem aplicadas e desta união entre os dois tipos de normas, floresceria o Direito.

Dentro do contexto proposto por Kelsen, de que as normas sempre buscam validade na norma superior e que essa busca força na norma superior precedente, essa última ligar-se-ia a "um usurpador individual ou uma assembleia" (KELSEN, 2000, p. 168), doravante será analisado o tema proposto em face de suas obras.

Pelo pensamento de Kelsen (2000), o CE de 1965 buscaria validade na Constituição de 1946, que seguiria um encadeamento lógico por meio das constituições de 1937, 1934, 1891 e 1824, essa que foi outorgada por Dom Pedro, após a independência do Brasil em 1822. Com a edição da $\mathrm{CF} / 88$, a norma superior voltou a entrar nos padrões de uma constituição normativa. Iniciou-se o processo de recepção das normas infraconstitucionais editadas sob a égide constitucional anterior, no qual muitas delas foram recepcionadas não por sua perfeita compatibilidade, mas pelo fato de que a simples extirpação do ordenamento jurídico seria mais nociva do que a sua continuidade.

Nesse diapasão, a edição de novas normas infraconstitucionais para substituir as normas que buscaram inicialmente validade em outro texto constitucional, foi um processo lento e no caso do CPP, foi realizado pela Lei $\mathrm{n}^{\mathrm{o}}$ 11.719/08. O CE/65 foi alterado inúmeras vezes por leis editadas sob o égide da Constituição de 1988, por exemplo, com a Lei no 9.041/95, que dispôs sobre a dispensa da multa referente ao alistamento eleitoral intempestivo, ou a Lei no $13.105 / 15$, que reduziu os custos das campanhas eleitorais, entre outras coisas.

Todavia, os artigos 355 a 364 não sofreram qualquer alteração desde a edição do CE/65, salvo a realizada pela Lei no 10.731/03, que institui a obrigatoriedade do depoimento pessoal no Processo Penal Eleitoral.

Dessa forma, a reforma implementada no CPP pela Lei $\mathrm{n}^{\circ}$ 11.719/08, constituiu real adequação do diploma aos preceitos da $\mathrm{CF} / 88$, 
para reforçar a noção de sistema proposta por Kelsen, que não admite normas conflitantes com a norma maior, pelo fato de que a norma superior é a que dá validade às demais.

Como o capítulo atinente a processo penal dentro do CE/ 65 não passou ainda por essa adequação (aos preceitos insculpidos na CF/88) e mais uma vez corroborando com a ideia de sistema jurídico defendida por Kelsen, em que não devem existir discrepâncias ao se amoldar um mesmo fato dentro do ordenamento jurídico, o uso do rito previsto no CPP para tratar as infrações penais eleitorais é o mais adequado dentro deste cenário, prevalecendo o critério lex posterior derogat priori.

Nesta senda, a noção de sistema apregoada por Kelsen se revela como o verdadeiro método de solução da antinomia jurídica sob estudo, eis que não deve haver conflito entre a norma superior e as normas inferiores, ou seja, os princípios constitucionais que regem o ordenamento desde 1988 induzem a aplicação do CPP em face do CE. E esse foi justamente o alinhamento extraído a partir da decisão do Tribunal Superior Eleitoral.

\section{Considerações finais}

O Código de Processo Penal, de 1941 foi editado sob a vigência da Constituição Federal de 1937, marcada pelo autoritarismo, ausência de sufrágio, tripartição de poderes e relativização dos direitos fundamentais. Ambos tiveram um autor em comum, Francisco Campos, que defendia ideais não-democráticos, restando clara no CPP a presunção de culpabilidade do réu. Já o Código Eleitoral, de 1965, foi editado sob égide da Constituição de 1946, mas instituído sob o governo militar e ditatorial de Castello Branco.

A Lei no 11.719/08 alterou o CPP para privilegiar à celeridade, à defesa efetiva, o sistema acusatório e o contraditório, adequando as disposições do CPP aos novos ditames da Constituição de 1988. Em breve síntese, instituiu a absolvição sumária e postergou o interrogatório do réu para o último ato da instrução. Em comparação com a redação original do CPP, a absolvição sumária era inexistente, tendo o réu que passar por todo o processo para ser inocentado. O interrogatório que era o primeiro ato processual passou a ser o último, permitindo ao réu se valer de todo o conteúdo produzido na instrução processual para ao final construir sua versão dos fatos. 
Com a reforma, surgiu a antinomia jurídica entre a aplicação do CPP e do CE, no que tange ao processamento dos crimes eleitorais. E por isso, defende-se a tese jurídica da aplicação dos critérios da hierarquia (lex superior derogat inferior) e da temporalidade (lex posterior derogat priori) para a solução desta antinomia jurídica. Para demonstrar a consistência de entendimento foi analisado um precedente do TSE, o Agravo Regimental em Recurso Especial Eleitoral no 2-75.2014.6.13.0044, que configura clara derrogação tácita da regra dos artigos 359 e 360, do Código Eleitoral e se alinha ao prisma jurídico de Hans Kelsen, a partir da ideia de sistema e de unidade do ordenamento jurídico. Conclui-se que a edição da Lei no 11.719/08 foi justamente para adequar o processo penal à Constituição de 1988, sendo, portanto, o contraditório prévio, uma garantia constitucional dos denunciados.

O posicionamento a ser adotado por parte dos Tribunais, portanto, deve conferir forte aplicabilidade aos direitos fundamentais e princípios constitucionais, assegurando ao cidadão o pleno gozo dos direitos previstos na Constituição de 1988, ainda que exista norma no ordenamento em sentido contrário. Observa-se, no REspe - Agravo Regimental em Recurso Especial Eleitoral nº 2-75.2014.6.13.0044 a opção pela interpretação sistemática do ordenamento jurídico, exaltando a força normativa da Constituição sobre as leis infraconstitucionais. Em decorrência dessa Corte ocupar o topo da pirâmide da justiça especializada, configura-se um norte para os demais Tribunais Regionais e Juízos Eleitorais espalhados pelo território nacional, em se curvar ao entendimento sedimentado. Evidenciou-se que o entendimento correto é que houve a derrogação tácita dos artigos 359 e 360, do Código Eleitoral e aplicação dos critérios da hierarquia e da temporalidade para a solução desta antinomia jurídica, devendo ser adotado o rito processual mais benéfico ao acusado, nos termos da Constituição de 1988 e da Lei n⿳⺈ 11.719/08.

\section{Referências}

BALEEIRO, Aliomar; LIMA SOBRINHO, Barbosa. Coleção Constituições brasileiras. Brasília: Senado Federal, 2012.

BONAVIDES, Paulo; ANDRADE, Paes de. História Constitucional do Brasil. 5. ed. Brasília: OAB, 2004. 
BOBBIO, Norberto. Teoria do Ordenamento Jurídico. Brasília: Editora Universidade de Brasília, 1995.

BRASIL. Câmara Federal. Projeto de Lei no 4.207 de 2001. Altera dispositivos do Decreto-Lei no 3.689, de 3 de outubro de 1941 - Código de Processo Penal -, relativos à suspensão do processo, Emendatio Libelli, Mutatio Libelli e aos Procedimentos. Disponível em: $<$ http://www2.camara.leg.br/proposicoesWeb/prop_mostrarintegra?codteor $=19605 \&$ filename $=$ PRL $+1+$ CCJC+\%3D\%3E+PL+4207/2001>. Acesso em: 6 jul. 2020.

. Constituição (1937). Constituição dos Estados Unidos do Brasil, de 1937. Disponível em: <http://www.planalto.gov.br/ccivil_03/Constituicao/ Constituicao37.htm> Acesso em: 6 jul. 2020.

Constituição (1946). Constituição de 18 de setembro de 1946.

Disponível em: <http://www.planalto.gov.br/ccivil_03/constituicao/constituicao46.htm>. Acesso em: 6 jul. 2020.

. Constituição (1988). Constituição de 05 de novembro de 1988.

Disponível em: <http://www.planalto.gov.br/ccivil_03/constituicao/constituicao.htm>. Acesso em: 6 jul. 2020.

. Decreto-lei no 3.689, de 03 de outubro de 1941. Código de Processo Penal. Disponível em: <http://www.planalto.gov.br/ccivil_03/decreto-lei/del3689.htm>. Acesso em : 6 jul. 2020.

. Decreto-lei no 7.586, de 28 de maio de 1945. Regula, em todo o país, o alistamento eleitoral e as eleições a que se refere o art. $4^{\circ}$ da Lei Constitucional no 9, de 28 de fevereiro de 1945. Disponível em: <http:// www.planalto.gov.br/ccivil_03/Decreto-Lei/1937-1946/Del7586.htm\#: :text $=$ DECRETO $\% 2$ DLEI $\% 20 \mathrm{~N} \% \mathrm{C} 2 \% \mathrm{BA} \% 207.586 \% 2 \mathrm{C} \% 20 \mathrm{DE} \% 20$ 28\%20DE $\% 20 \mathrm{MAIO} \% 20 \mathrm{DE} \% 201945 . \&$ text $=$ INTRODU $\% \mathrm{C} 3 \% 87 \%$ C3\%83O-,Art.,que $\% 20$ se $\% 20$ refere $\% 20 \mathrm{o} \% 20$ art.\&text $=2 \% \mathrm{C} 2 \% \mathrm{BA} \% 20$ $\mathrm{S} \% \mathrm{C} 3 \% \mathrm{~A} 3 \mathrm{o} \% 20$ eleitores $\%$ 20os $\% 20$ brasileiros,alistados $\% 20 \mathrm{na} \% 20$ conformidade $\% 20$ desta $\% 201$ ei>. Acesso em: 6 jul. 2020.

. Lei no 4.737, de 15 de julho de 1965. Institui o Código Eleitoral. Disponível em: <http://www.planalto.gov.br/ccivil_03/leis/14737.htm>. Acesso em: 6 jul. 2020.

. Lei $\mathrm{n}^{\mathrm{o}} 11.719$, de 20 de junho de 2008. Altera Dispositivos do Decreto-lei no 3.689, de 3 de outubro de 1941 - Código de Processo Penal, Relativos à Suspensão do Processo, Emendatio Libelli, Mutatio Libelli e aos procedimentos. Disponível em: <http://www.planalto.gov.br/ccivil_03/_Ato20072010/2008/Lei/L11719.htm>. Acesso em: 6 jul. 2020. 
. Lei no 13.165 , de 29 de setembro de 2015. Altera as Leis nos 9.504, de 30 de setembro de 1997, 9.096, de 19 de setembro de 1995, e 4.737, de 15 de julho de 1965 - Código Eleitoral, para reduzir os custos das campanhas eleitorais, simplificar a administração dos Partidos Políticos e incentivar a participação feminina. Disponível em: <http://www.planalto.gov.br/ccivil_03/_ Ato2015-2018/2015/Lei/L13165.htm>. Acesso em: 6 jul. 2020.

. Resolução nº 215, de 02 de dezembro de 1945. Disponível em: <http://www.justicaeleitoral.jus.br/arquivos/tse-resolucao-215-parlamento-nacional/rybena_pdf?file=http://www.justicaeleitoral.jus.br/arquivos/tse-resolucao-215-parlamento-nacional/at_download/file>. Acesso em: 6 jul. 2020.

. Supremo Tribunal Federal. Ação Direta de Inconstitucionalidade no 2.649. Relator: Ministra Cármen Lúcia. Brasilia, DF, 8 maio 2008. DJe 17.10.2008. Disponível em: < http://redir.stf.jus.br/paginadorpub/paginador. jsp?docTP=AC\&docID=555517>. Acesso em: 7 jul. 2020.

. Tribunal Superior Eleitoral (TSE). Agravo regimental no recurso especial eleitoral no 2-75.2014.6.13.0044. Relator: Ministro Tarcísio Vieira De Carvalho Neto. Brasília, DF, 8 março 2018. Dje de 13.4.2018. Disponível em: $<$ http://inter03.tse.jus.br/sjur-pesquisa/pesquisa/actionBRSSearchServers. do?tribunal $=$ TSE $\&$ livre $=\&$ classe $=$ RESPE\&numeroProcesso $=275>$. Acesso em: 6 jul. 2020.

\section{Tribunal Superior Eleitoral (TSE). Agravo regimental no recurso} especial eleitoral no 2-75.2014.6.13.0044. Relator: Ministro Tarcísio Vieira de Carvalho Neto. Brasília, DF, 8 março 2018. Dje de 13.4.2018. Disponível em: $<$ http://inter03.tse.jus.br/sjur-pesquisa/pesquisa/actionBRSSearchServers. do?tribunal $=$ TSE $\&$ livre $=\&$ classe $=$ RESPE\&numeroProcesso $=275>$. Acesso em: 6 jul. 2020.

. Tribunal Superior Eleitoral (TSE). Habeas Corpus $\mathbf{n}^{\underline{0}}$

69-09.2012.6.00.0000. Relator: Ministro Dias Toffoli. Brasília, DF, 29 outubro 2013. DJe de 12.2.2014. Disponível em:<http://inter03.tse.jus.br/InteiroTeor/ pesquisa/actionGetBinary.do?tribunal $=$ TSE $\&$ processoNumero $=6909 \&$ processoClasse $=$ HC\&decisaoData $=20131029>$. Acesso em: 6 jul. 2020.

. Tribunal Superior Eleitoral (TSE). Habeas Corpus no $\mathbf{n}^{2957-}$ 19.2010.6.00.0000. Relator: Ministro Marcelo Ribeiro. Brasília, DF, 16 novembro 2010. DJe de 2.2.2011. Disponível em: <https://tse.jusbrasil.com.br/jurisprudencia/18814738/habeas-corpus-hc-295719-rj/inteiro-teor-104143324>. Acesso em: 6 jul. 2020.

CANOTILHO, José Joaquim Gomes. Direito Constitucional e Teoria da Constituição. 7. ed. Coimbra: Almedina, 2000. 
CASTRO, Celso. O golpe de 1964 e a instauração do regime militar. FGV CPDOC. Disponível em: <http://cpdoc.fgv.br/producao/dossies/FatosImagens/Golpe1964>. Acesso em: 7 jul. 2020.

FICHTNER, José Antônio; GAMA FILHO, Fabiana. FGV - CPDOC. Disponível em: <http://www.fgv.br/cpdoc/acervo/dicionarios/verbete-tematico/ codigo-eleitoral-2>. Acesso em: 7 jul. 2020.

GOMES, José Jairo. Direito Eleitoral. 12. ed. São Paulo: Atlas, 2016.

GOMES, Júlio de Souza; ZAMARIAN, Lívia Pitelli. As Constituições do Brasil. Birigui: Boreal, 2012.

KELSEN, Hans. Teoria Geral do Estado e do Direito. São Paulo: Martins Fontes, 2000.

, Hans. Teoria Pura do Direito. São Paulo: Martins Fontes, 1999.

MOURA, Maria Thereza Rocha de Assis; SANTOS, Leandro Galluzzi. 20 anos de vigência da Constituição da República e o processo penal. In: MORAES, Alexandre de (Org.). Os 20 anos da Constituição da República Federativa do Brasil. São Paulo: Atlas, 2009.

SANTOS, Marco Antonio Cabral dos. Francisco Campos: um ideólogo para o Estado Novo. In: Locus Revista de História, Juiz de Fora, v. 13, n. 2, p.31-48, jul. 2007. Bimestral. Universidade Federal de Juiz de Fora. Disponível em: < https://periodicos.ufff.br/index.php/locus/issue/view/893 >. Acesso em: 6 jul. 2020.

TRIBUNAL SUPERIOR ELEITORAL (TSE). Assembleia Constituinte de 1946. Disponível em: <http://www.tse.jus.br/jurisprudencia/julgados-historicos/assembleia-constituinte-1946>. Acesso em: 6 jul. 2020.

VILLA, Marco Antonio. A História das Constituições Brasileiras. 2. ed. São Paulo: Leya, 2011.

Marco Aurélio Rodrigues da Cunha e Cruz - Doutor em Direito Constitucional pela Universidad de Sevilla. Professor Permanente - PPGD-Unoesc. Advogado. E-mail: mar. cunhaecruz@gmail.com.

Adriana Martins Ferreira Festugatto - Mestre em Direitos Fundamentais pela UNOESC. Servidora do quadro do Tribunal Regional Eleitoral de Santa Catarina, lotada no 094ㄹ Zona Eleitoral. E-mail: adrianafestugatto@gmail.com.

Guilherme Apolinário Aragão - Especialista em Direito Eleitoral pelo IDP-DF. Professor. Advogado. E-mail:guilherme.aragao@gaadveconsultoria.com.br. 